\title{
CARBON SOURCES EFFECT ON PECTINASE PRODUCTION FROM ASPERGILLUS JAPONICUS 586
}

\author{
Maria F. S. Teixeira ${ }^{1}$; José L. Lima Filho²; Nelson Durán ${ }^{3 *}$ \\ ${ }^{1}$ Laboratório de Microbiologia, Universidade de Amazonas, Manaus, AM, Brasil. ${ }^{2}$ Laboratório de Bioquímica, \\ Universidade Federal de Pernambuco, PE, Brasil. ${ }^{3}$ Instituto de Química, Laboratório de Química Biológica, \\ Universidade Estadual de Campinas, Campinas, SP, Brasil
}

Submitted: January 27, 2000; Returned to authors for corrections: July 18, 2000; Approved: November 07, 2000

\begin{abstract}
The effect of different carbon sources on the pectinesterases, endo- and exo-polygalacturonase activities from Aspergillus japonicus 586 was evaluated in liquid media (Manachini solutions) supplemented with different substrate concentrations. The culture medium was inoculated with $5.10^{6} \mathrm{spores} / \mathrm{ml}$ and mantained under agitation $(140 \mathrm{rpm})$, at $30^{\circ} \mathrm{C}$, during $122 \mathrm{~h}$. The enzyme evaluation was carried out $24 \mathrm{~h}$ after filtration. The crude extract from A. japonicus 586 indicated that the best enzymatic activities were afforded in the presence of $0.5 \%$ pectin (pectinesterease), $0.2 \%$ pectin and $0.2 \%$ glycerol (endopolygalacturonase), and $0.5 \%$ pectin associated to $0.5 \%$ glucose (exopolygalacturonase). Carbon sources concentration, isolated or associated, significantly affects the pectinesterase, and endo- and exopolygalacturonase activities. Pectin, glucose and saccharose, when added to the culture medium in high concentrations, exhibited a repression effect on all the analyzed enzymes.
\end{abstract}

Key words: pectinases, Aspergillus japonicus, enzyme, galacturonase, pectinesterases

\section{INTRODUCTION}

Among fungal enzymes, pectinases are associated with development, fruit ripening and degradation of the pectic substances in the vegetal cell wall. This degradative process plays an important role in food technology, due to reduction in time of filtration and to the volume increase, and juice clarification. This process leads to a more stable and concentrated product $(1,7,9,11,30)$.

The main sources for the pectinolytic complex enzymes are yeast, bacteria and a large variety of filamentous fungi, for which the most relevant ones are Aspergillus $(3,18,20,24)$

Through studies with microorganisms, experimental assays demonstrated that the enzyme synthesis is correlated with the quality and concentration of the carbon and nitrogen sources. In this area, research is more advanced with bacteria than with fungi. The studies of pectinases synthesis from Aspergillus, Fusarium and Verticillium, among others, show that it is induced mainly by pectin or pectin associated to other substances $(1,4)$. Although pectolyase from $A$. japonicus is commercially available from SIGMA (USA), very few studies with the other pectinase complex have been recently published $(1,10)$. Pectin lyase from A. japonicus was previously published $(16,22)$.

In light of the importance of the regulation study of the enzyme synthesis of pectinolytic complex, the influence of a variety of carbon sources on the pectinesterase, and endoand exopolygalacturonase production from a previously selected A. japonicus $586(27,28)$ was studied in order to obtain high enzymatic levels.

\section{MATERIALS AND METHODS}

A. japonicus 586 was isolated by the methodology previously described $(5,8,26)$.

Pectinesterase, endo- and exopolygalacturonase from $A$. japonicus 586 were evaluated using different carbon sources

\footnotetext{
* Corresponding author. Mailing address: Instituto de Química, Laboratório de Química Biológica, Universidade Estadual de Campinas-UNICAMP, Caixa Postal 6154, CEP 13083-970, Campinas, SP, Brasil. E-mail: duran@iqm.unicamp.br
} 
(Table 1) as follows: Culture media were prepared in triplicate by adding a spore suspension ( $50 \mathrm{ml}$ Manachini solution, $\mathrm{pH}$ 2.5) of $5.10^{6}$ spores $/ \mathrm{ml}$ to the medium at $30^{\circ} \mathrm{C}$, agitated $(140 \mathrm{rpm})$ for $120 \mathrm{~h}$. After each period of $24 \mathrm{~h}$, the mycelial mass was filtered (Millipore $0.45 \mathrm{~mm}$ ) and the extract dialyzed and submitted to enzymatic analysis.

Table 1. Carbon sources effect on pectinases production from Aspergillus japonicus 586

\begin{tabular}{ll}
\hline Carbon Sources & Concentration \% $(\mathrm{w} / \mathrm{v})$ \\
\hline saccharose & 0.8 \\
pectin/saccharose & $0.8 / 0.8$ \\
pectin/saccharose & $0.2 / 0.2$ \\
glucose & 0.5 \\
pectin/glucose & $0.5 / 0.5$ \\
pectin & 0.25 \\
pectin & 0.50 \\
pectin & 1.00 \\
glycerol & 0.20 \\
pectin/glycerol & $0.2 / 0.2$ \\
\hline
\end{tabular}

Pectinesterase [PE (E.C.3.1.1.11)] activity: This enzyme was evaluated by the $\mathrm{pH}$ decrease of the medium and by titration of the carboxylic groups using a modified methodology $(19,23)$, in $2.0 \mathrm{ml}$ of $1 \%(\mathrm{p} / \mathrm{v})$ citric pectin solution in $0.025 \mathrm{M}$ Tris-acetate buffer $\mathrm{pH} 6.5$ and $1.0 \mathrm{ml}$ of enzymatic dialyzed crude extract. The blank was prepared in the same way except that the culture extract was substituted by the buffer solution. The enzymatic reaction was carried out at $50^{\circ} \mathrm{C}$ for $2 \mathrm{~h}$ and then quenched in a boiling water bath for 3 minutes. Then, the samples were cooled in an ice-bath and titrated with $0.01 \mathrm{M} \mathrm{NaOH}$ solution. A pectinesterase unit (U) was defined as the quantity of enzyme which liberates a microequivalent of carboxylic group in $1 \mathrm{~h}$ of reaction under the described conditions.

Endopolygalacturonase [ENDO-PG (E.C.3.2.1.15)] activity: ENDO-PG activity was measured viscosimetrically by the method of Tuttobello and Mill (29) using the following conditions: $250 \mathrm{ml}$ of the dialyzed crude enzymatic extract were added to $5.5 \mathrm{ml} 0.2 \%$ (w/v) citric pectin in $0.025 \mathrm{M}$ acetate buffer, pH 5.0 and $1.0 \mathrm{mM}$ EDTA. The blank was prepared as before except that $250 \mathrm{ml}$ buffer solution were added instead of the crude enzyme. The reaction was incubated at $50^{\circ} \mathrm{C}$ for 10 minutos. The viscosity decrease was determined following Tuttobello and Mill (29) methodology. A viscosimetric unit (UV) was defined as the enzyme quantity needed to decrese by $50 \%$ the initial viscosity per min under the defined conditions (15). The enzymatic activity was given in $\mathrm{UV} / \mathrm{ml}$.
Exopolygalacturonase [EXO-PG (E.C.3.2.1.82] activity: The EXO-PG activity was measured by quantification of reductant groups liberated from the pectin solution by the DNS method (17). To $250 \mathrm{ml} 0.5 \%(\mathrm{w} / \mathrm{v})$ of citric pectin in $0.025 \mathrm{M}$ acetate buffer, $\mathrm{pH} 5.0,1 \mathrm{mM}$ EDTA, $250 \mathrm{ml}$ of the dialyzed enzymatic extract were added. The blank was prepared as described above. After $10 \mathrm{~min}$ at $50^{\circ} \mathrm{C}, 0.5 \mathrm{ml} \mathrm{DNS}$ solution was added to each tube and boiled for $5 \mathrm{~min}$. After cooling $5 \mathrm{ml}$ of destilled water was added, agitated and the absorbance at $575 \mathrm{~nm}$ was measured. The reductant sugar values were determined from a standard curve of monogalacturonic acid. One enzymatic unit (U) was defined by the enzyme quantity which liberates a mmol of monogalacturonic acid per min under the described experimental conditions. The enzymatic activity was expressed in $\mathrm{mmol} / \mathrm{ml}$.

\section{RESULTS AND DISCUSSION}

Results for the different cultures of A. japonicus 586 producing pectinolytic enzymes are shown in Figs. 1-3. A. japonicus 586 metabolized all carbon sources in the culture media. The best values of pectinolytic enzymes were found in the presence of pectin as substrate. The enzymatic activities were affected by the co-substrate type and their concentration. These results are in agreement with previous reports in the literature with Aspergillus niger and Aspergillus sp. (1,21).

Fig. 1 shows that, among the carbon sources, 5\% pectin after $72 \mathrm{~h}$ incubation showed the best pectinesterase activity (5.7 U/ml). In the presence of the same substrate, after increasing (double) or decreasing (half) the final concentration, the pectinesterase activity was reduced after $48 \mathrm{~h}$ by $39 \%$ and $30 \%$, respectively. These results were indicative of an enzymatic repression, probably due to the presence of some pectin degradation products which act as enzyme inhibitors or different molecular forms of the pectinesterases sensible to these compounds. These results are also in agreement with those obtained by Leone and Van der Heuvel (12) with Botrytis cinerea, which showed that the different isoenzymes produced were affected by the type and concentration of the substrate present in the culture medium. Furthermore, Crotti (6) mentioned that a low concentration of these substrates was inefficient to increase the pectinases production in Penicillium frequentans cultures. During the fermentation process, a maximal pectinesterase activity $(5.5 \mathrm{U} / \mathrm{ml})$ at $48 \mathrm{~h}$, which was $3.2 \%$ lower in activity than in $5 \%$ pectin was observed. In the presence of $0.5 \%$ pectin and $0.5 \%$ glucose, a value of $1.9 \mathrm{U} / \mathrm{ml}$ at $72 \mathrm{~h}$ as the maximal enzymatic activity was found.

The results showed that the pectinesterase activity produced by A. japonicus 586 was susceptible to catabolic repression when $0.5 \%$ glucose or $0.8 \%$ saccharose were used. The maximal enzymatic activity observed in these cases were 


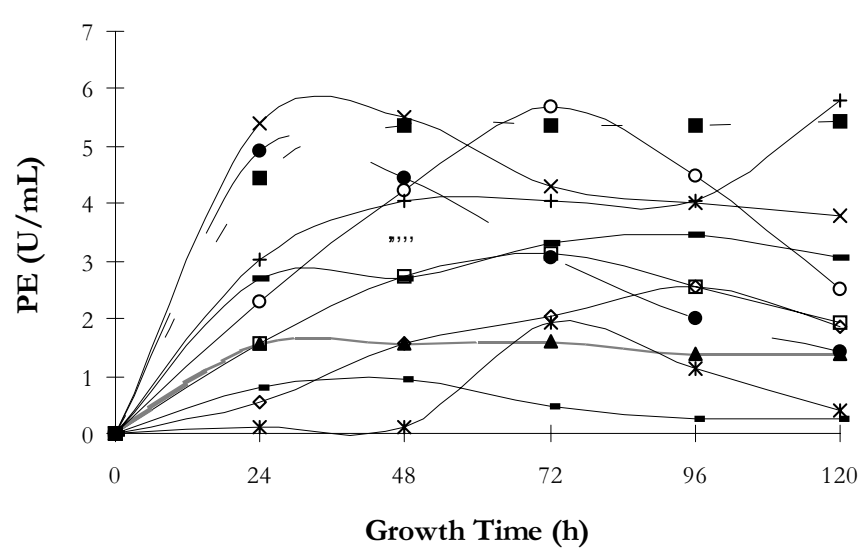

Figure 1. Effect of different carbon sources on the pectinesterase (PE) activities produced by A. japonicus 586, in Manachini solution, $\mathrm{pH} 2.5$, at $30^{\circ} \mathrm{C}$, agitation (140 rpm), $120 \mathrm{~h}$ : (- $\square$-) Pectin $(0.2 \%)+$ Saccharose $(0.2 \%),(-\diamond-)$ Pectin $(0.8 \%)+$ Saccharose $(0.8 \%),(-\mathbf{\Delta}-)$ Saccharose $(0.8 \%),(-\mathrm{X}-)$ Pectin $(0.2 \%)+$ Glucose $(0.2 \%),\left(-*_{-}\right)$Pectin $(0.5 \%)+$ Glucose $(0.5 \%),(-\boxminus-)$ Glucose $(0.5 \%),(-\equiv-)$ Pectin $(0.25 \%)$, (-O-) Pectin (0.5\%), (-+-) Pectin (1.0\%), (-๑-) Pectin (1.0\%) + Glycerol $0.2 \%,(-\boldsymbol{-}-)$ Glycerol $(0.2 \%)$.

$0.96 \mathrm{U} / \mathrm{ml}$ and $1.61 \mathrm{U} / \mathrm{ml} / \mathrm{h}$, during $48 \mathrm{~h}$ and $72 \mathrm{~h}$, respectively.

In the presence of culture medium associated with different substrates, e.g. $0.2 \%$ pectin and $0.2 \%$ glucose, reduction of $65.1 \%$ and $66.2 \%$ relative to those obtained with $0.2 \%$ pectin and $0.2 \%$ glucose or only $0.5 \%$ pectin (Fig. 1) was observed. In the presence of $0.2 \%$ pectin and $0.2 \%$ saccharose at $72 \mathrm{~h}$, an enzymatic activity value of $3.1 \mathrm{U} / \mathrm{ml}$ was observed which was higher than that for $0.8 \%$ pectin and $0.8 \%$ saccharose $(2.5 \mathrm{U} / \mathrm{ml})$, for a culture period of $96 \mathrm{~h}$ (Fig. 1). These activities were lower than that in $0.5 \%$ pectin.

Pectinesterase activity from A. japonicus 586 was susceptible to catabolic repression with high glucose and saccharose concentrations. In the case of A. niger, no repression was observed and Aguilar and Huitron (1), and Griffin (10) suggested that the increase of pectinesterase, when glucose or saccharose was present in association with pectin in low concentrations, was probably due to that the glucose or saccharose which were metabolized before pectin consumption, producing enough material and energy to induce a rapid microbial growth without any repression.

Endopolygalacturonase from A. japonicus 586 (Fig. 2), in the presence of pectin and glycerol or glycerol alone for $120 \mathrm{~h}$, had the best conditions for maximal enzymatic activities (0.592 UV/ml and $0.565 \mathrm{UV} / \mathrm{ml}$, respectively). These results are indicative that endopolygalacturonase is induced by glycerol under the analyzed conditions, and this corroborates the published results by Aguilar and Huitron (2) in the cultures of Aspergillus sp. CH-Y-1043.

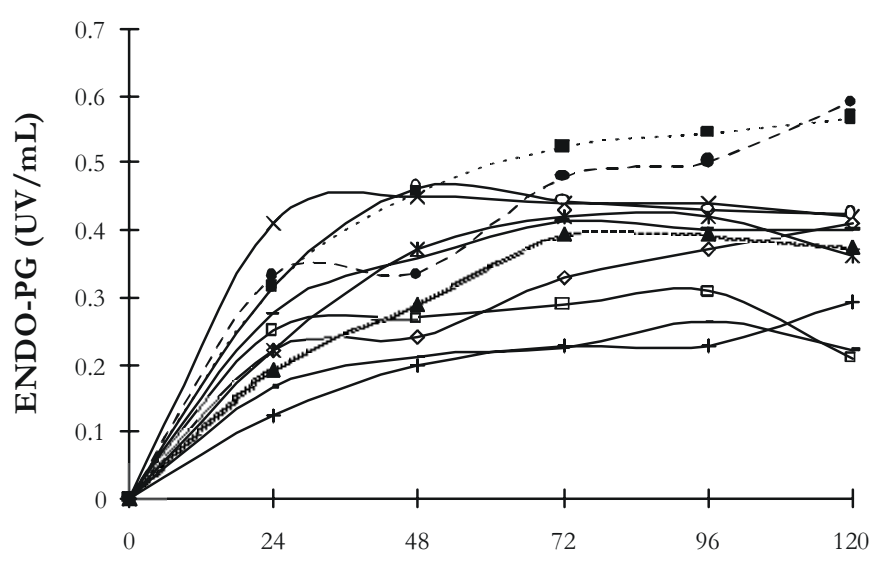

Growth Time (h)

Figure 2. Effect of different carbon sources on the endopolygalacturonase (Endo-PG) activities produced by A. japonicus 586, in Manachini solution, $\mathrm{pH} 2.5$, at $30^{\circ} \mathrm{C}$, agitation (140 rpm), during $120 \mathrm{~h}$. The same symbols as described in Fig.1.

Fig. 2 shows that the lowest endopolygalacturonase was expressed by A. japonicus 586 cultures in the presence of $0.5 \%$ glucose or $1 \%$ pectin. The maxima activities measured at $96 \mathrm{~h}$ and $120 \mathrm{~h}$ were $0.226 \mathrm{UV} / \mathrm{ml}$ and $0.294 \mathrm{UV} / \mathrm{ml}$, respectively. These data suggested that in glucose or pectin media under the analyzed concentration, a catabolic repression is present. Probably, this is due to the presence of a high galacturonic acid concentration from pectin degradation. This is in agreement with the results of Aguilar and Huitron (1), and of Maldonado and Callieri (13) which showed that the production of these enzymes is directly correlated with the substrate concentration as shown in Aspergillus sp. and Aspergillus niger cultures. Different carbon sources such as galacturonic acid, glucose, pectin and pectin-glucose were used.

With respect to the endopolygalacturonase activity in the A. japonicus 586 cultures (Fig. 2) containing $0.2 \%$ and $0.2 \%$ glucose, the enzymatic extract exhibited an increase in enzymatic activity during the first $24 \mathrm{~h}(0.45 \mathrm{UV} / \mathrm{ml})$. In the presence of $0.5 \%$ pectin and $0.5 \%$ glucose for $72 \mathrm{~h}$, the maximum endopolygalacturonase activity was $0.42 \mathrm{UV} / \mathrm{ml}$. This value represents a reduction of only $9.3 \%$ compared to that obtained in $0.5 \%$ pectin and an increase of $46.2 \%$, when compared with those obtained with $0.5 \%$ glucose. These findings are comparable to those found by Maldonado and Callieri (13), and Aguilar and Huitron (1).

In the presence of $0.25 \%$ or $0.5 \%$ pectin, A. japonicus 586 (Fig. 2), showed a significative endopolygalacturonase activity in similar way as obtained with associated substrates (pectin and glucose). The maximum activities were obtained at 72 and $48 \mathrm{~h}(0.414 \mathrm{UV} / \mathrm{ml}$ and $0.463 \mathrm{UV} / \mathrm{ml}$, respectively). 
Scaling the activity values to $100 \%(0.592 \mathrm{UV} / \mathrm{ml})$ produced by $0.2 \%$ pectin and $0.2 \%$ glycerol a $30.1 \%$ and $21.8 \%$ reductions, respectively, were found. Comparing the maximal production of endopolygalacturonase in pectin and glycerol to that of $0.5 \%$ pectin, it is more advantage to use pectin as a substrate in the fermentative process than pectin and glycerol for economical reasons, because it is possible to obtain a good enzymatic level activity in a short cultivation period.

Fig. 2 shows that when A. japonicus 586 was cultivated in $0.8 \%$ saccharose alone, $0.2 \%$ pectin associated with $0.2 \%$ saccharose or $0.8 \%$ pectin associated with $0.8 \%$ saccharose, endopolygalacturonase activities were higher than that at $0.8 \%$ saccharose alone $(0.394 \mathrm{UV} / \mathrm{ml}$ at $72 \mathrm{~h})$. In the medium culture where the pectin was associated with saccharose, an increase of the activity with increase of the concentration of these substrates was observed. The maxima activities observed were $0.310 \mathrm{UV} / \mathrm{ml}(0.2 \%$ pectin and $0.2 \%$ sacharose $)$ and $0.370 \mathrm{UV} / \mathrm{ml}(0.8$ pectin and $0.8 \%$ saccharose $)$ after $96 \mathrm{~h}$ incubation. Therefore, this experiment demonstrated that endopolygalacturonase was more active in the $0.8 \%$ saccharose medium than those in pectin $(0.2 \%$ or $0.8 \%)$ associated with saccharose $(0.2 \%$ or $0.8 \%)$.

Fig. 3 shows the results for the exopolygalacturonase production from A. japonicus 586. Among the analyzed substrates, the maximal exopolygalacturonase activity at $48 \mathrm{~h}$ $(0.500 \mathrm{U} / \mathrm{ml})$ was obtained in the presence of $0.5 \%$ pectin and $0.5 \%$ glucose. With the same substrates at lower concentrations $(0.2 \%$ pectin and $0.2 \%$ glucose) the maximum activity was $0.370 \mathrm{U} / \mathrm{ml}$, which was $26.0 \%$ lower than those obtained with $0.5 \%$ pectin and $0.5 \%$ glucose. These results showed that the glucose in the presence of high concentrations of pectin promotes high exopolygalacturonase activity. These results suggested that glucose in low concentration and in the

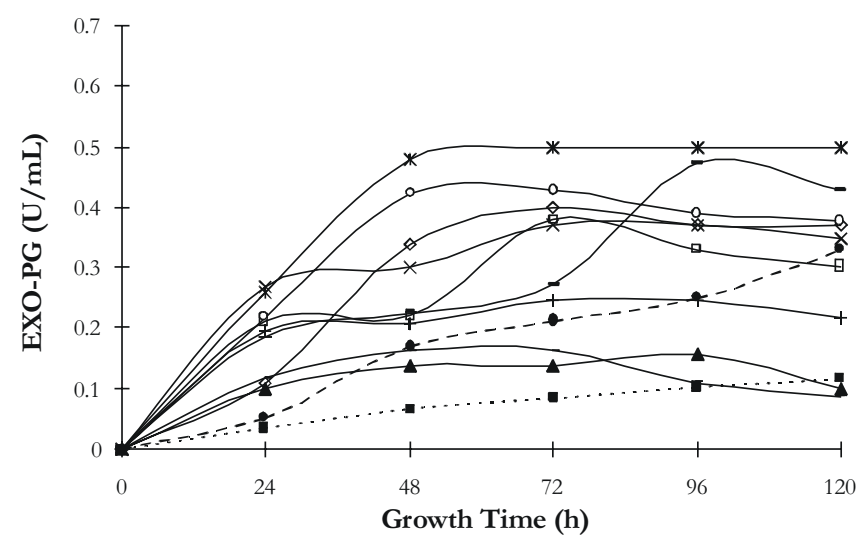

Figure 3. Effect of different carbon sources on the exopolygalacturonase activities produced by A. japonicus 586, in Manachini solution, $\mathrm{pH}$ 2.5 , at $30^{\circ} \mathrm{C}$, agitation ( $140 \mathrm{rpm}$ ), during $120 \mathrm{~h}$. The same symbols as described in Fig.1. presence of pectin was not enough to stimulate the exopolygalacturonase activity, as observed at high substrate concentrations. Similar results were observed by Solis-Pereira et al. (25) in cultures suplemented with $10 \%$ glucose.

In the cultures with $0.5 \%$ glucose alone, and $0.8 \%$ saccharose and $0.2 \%$ glycerol, the exopolygalacturonase activities decreased significantly during the A. japonicus 586 growth (Fig. 3). In these extracts the highest values obtained were $0.114 \mathrm{U} / \mathrm{ml}, 0.163 \mathrm{U} / \mathrm{ml}$ and $0.158 \mathrm{U} / \mathrm{ml}$, respectively. With the exception of the repression effect of glycerol, the activity repression with glucose and saccharose were similar to those published for Aspergillus sp. CH-Y-1043 and Aspergillus niger $(2,14)$.

The results showed that in the media containing pectin associated with glycerol, a repression of the enzymatic activities occurred. The explanation probably is the same as discussed before by Griffin (10).

When only pectin is used, the exopolygalacturonase activity was higher than that from the culture containing $0.25 \%$ pectin $(0.474 \mathrm{U} / \mathrm{ml})$ and $0.5 \%$ pectin $(0.427 \mathrm{U} / \mathrm{ml})$. In the cultures where a $1 \%$ pectin was used, the enzymatic activities decreased to $0.247 \mathrm{U} / \mathrm{ml}$, which represents a $47.9 \%$ reduction when compared with those obtained at $0.25 \%$ pectin. This reduction was $50.6 \%$ when compared to $100 \%$ of the activity obtained with $0.5 \%$ pectin and $0.5 \%$ glucose. These data show that with the increase of the pectin concentration, the activity is more significative, probably due to the presence of the metabolic products from pectin or to the presence of isoenzymes, as discussed before.

In summary, A. japonicus 586 exhibits high pectinesterase, and endo and exopolygalacturonase production in culture media supplemented with pectin and co-substrates such as glucose, saccharose and glycerol. The cabon sources concentration, isolated or associated, affects the pectinolytic activities. The best carbon sources for high enzymatic activities were $0.5 \%$ pectin (pectinesterase), $0.2 \%$ pectin and/or $0.2 \%$ glycerol (endopolygalacturonase) and pectin associated to glucose (exopolygalacturonase). Pectin, glucose and saccharose, when added to the media in high concentrations, have a repression effect on the studied enzymatic activities.

\section{RESUMO}

\section{Efeito das fontes de carbono na produção de pectinase por Aspergillus japonicus 586}

Foi avaliado o efeito de diferentes fontes de carbono na atividade de pectinesterease, endo - e exo-polygalacturonase de Aspergillus japonicus 586, em meio líquido (soluções de Manachini) suplementado com diferentes concentrações de substratos. O meio de cultura foi inoculado com $5 \times 10^{6}$ esporos/ $\mathrm{ml}$ e mantido sob agitação (140 rpm), a $30^{\circ} \mathrm{C}$, durante $120 \mathrm{~h}$. A 
avaliação das enzimas foi realizada a cada 24 h após filtração. $\mathrm{O}$ extrato cru de A. japonicus 586 mostrou que as melhores atividades enzimáticas foram obtidas na presença de $0,5 \%$ pectina (pectinestarease), $0,2 \%$ pectina e $0,2 \%$ glicerol (endopoligalacturonase) e $0,5 \%$ pectina associada a $0,5 \%$ glicose (exopoligalacturonase). Diferentes concentrações de fontes de carbono, isoladas ou associadas afetaram significativamente as atividades de polinesterase, endo- e exopoligalacturonase. Quando adicionado pectina, glicose e sacarose em altas concentrações, ao meio de cultura, observouse um efeito de repressão de todas as enzimas analisadas.

Palavras-chave: Pectinases, Aspergillus japonicus, enzima, galacturonase, pectinesterases

\section{REFERENCES}

1. Aguilar, G.; Huitron, C. Stimulation of the production of extracellular pectinolytic activities of Aspergillus sp. by galacturonic acid and glucose addition. Enzyme Microbial Tecnhol.. 9: 690-696, 1987.

2. Aguilar, G.; Huitron, C. Constitutive exo-pectinase produced by Aspergillus sp. CH - Y - 1043 on different carbon source. Biotechnol. Lett. 12: 655-660, 1990.

3. Ahmad, R.; Ahmad, S.; Igbal, J.; Baig, M.A. Shake flask studies for preliminaries by Aspergillus foetidus. Pak. J. Sci. Res. 49: 36-39, 1997.

4. Call, H. P.; Walter, J.; Emeis, C. C. Maceration activity of an endopolygalacturonase from Candida macedoniensis. J. Food Biochem. 9: 325-348, 1985.

5. Carvalho, S.M. de S.; Teixeira, M.F.S.; Esposito, E.; Machuca, A.; Ferraz, A.; Durán, N. "Amazonian lignocellulosic materials-I: Fungal screening for decayed Laurel and Cedar trees", Appl. Biochem. Biotechnol. 37: 33-38, 1992.

6. Crotti, L. B. Estudos da produção de pectinases por Talaromyces flavus em cultura submersa. Riberão Preto, S.P. 1993, 96p. (M.Sc.Thesis, Universidade de São Paulo/Faculdade de Ciências Farmacêuticas de Ribeirão Preto).

7. Dinella, C.; Stagni, A.; Lanzarini, G.; Laus, M. Immobilized pectinase efficiency in the depolymerization of pectin in a model solution and apple juice. Prog. Biotechnol. 14: (Pectins and Pectinases), 971-978, 1996.

8. Fernandes, OC.C.; Teixeira, M.F.S.; Oliveira, L.P.; Durán, N. Potential enzymes for recycling paper from Aspergillus strains, Proc. Fourth Brazilian Symp. on the Chem. of lignins and Other Wood Comp.(E.H.M. Melo and M.C.Pimentel, Eds.), December 1995, Recife, Pernambuco, 5, 259-260, 1995.

9. Grassin, C.; Fauquembergue, P. Application of pectinases in beverages. Prog. Biotechnol. 14: (Pectins and Pectinases), 453-462, 1996

10. Griffin, D. H. Fungal physiology. 2nd. ed. New York: Wiley-liss, 1994, 458p.

11. Heldt-Hansen, H.P.; Kofod, L.V.; Budolfsen, G.; Nielsen, P.M.; Huttel, S.; Bladt, T. Application of tailor-made pectinases. Prog. Biotechnol. 14: (Pectins and Pectinases), 463-474, 1996.
12. Leone, G.; Van den Heuvel, J. Regulation by carbohydrates of the sequential in vitro production of pectic enzymes by Botrytis cinerea. Can. J. Bot. 65: 2133-2142, 1987.

13. Maldonado, M. C.; Callieri, D. A. S. Influence of environmental conditions on the production of pectinesterase and polygalacturonase by Aspegillus niger. Mircen J. 5: 327-333, 1989.

14. Maldonado, M. C.; Saad A. M. S.; Callieri, D. A. S. Regulatory aspects of the synthesis of polygalacturonase and pectinesterase by Aspergillus niger. Sci. Aliments. 9: 101-110, 1989.

15. Manachini, P. L.; Fortina, M. G.; Parini, C. Purification and properties of an endopolycalacturonase produced by Rhizopus stolonifer. Biotechnol. Lett.. 9: 219-224, 1987.

16. Mathieu, Y.; Jouanneau, J.P.; Thomine, S.; Lapons, D.; Guern, J. Cytosolic protons as secondary messengers in elicitor-induced defense responses. Biochem. Soc. Symp. 60: 113-130, 1994.

17. Miller G. L. Use of dinitrosalicylic acid reagent for determination of reducing sugar. Anal. Chem. 31: 426-428, 1995.

18. Nair, S. R.; Rakshit, S.K.; Panda, T. Effect of carbon on the synthesis of pectinase by Aspergilli. Bioprocess Eng. 13: 37-40, 1995.

19. Nasuno, S.; Starr, M. P. Polygalacturonase of Erwinia carotovora. J. Biol.. Chem. 241: 5298-5306, 1966.

20. Perenirova, L.; Benen, J.A.E.; Visser, J. pgaE encodes a fourth member of the endopolygalacturonase gene family from Aspergillus niger. Eur. J. Biochem. 251: 72-78, 1998.

21. Rombouts, F. M.; Pilnik, W. Pectic enzymes. In: Rose, A. H. (Ed.) Economic Microbiology. London: Academic Press, 1980, p.227-282.

22. Rout-Mayer, M.-A.; Mathieu, Y.; Cazolé, A.-C.; Guern, J. Extracellular alkalinization and oxidative burst induced by fungal pectin lyase in tobacco cells are not due to the perception of oligogalactoronide fragments. Plant Physiol. Biochem. 35: 321-330, 1997.

23. Siéssere, V.; Said, S.; Fonseca, M. J. V. Extracellular polygalacturonases from Penicillium frequentans: separation and regulatory aspects. $J$. Gen. Microbiol. 138: 1801-1805, 1992.

24. Solis, S.; Flores, M.E.; Huitron, C. Improvement of pectinase production by interspecific hydrides of Aspergillus strains. Lett. Appl. Microbiol. 24: 77-81, 1997.

25. Solis-Pereira, S.; Favela-Torres, E.; Viniegra-González, G.; GutiérrezRojas, M. Effects of different carbon sources on the synthesis of pectinase by Aspergillus niger in submerged and solid state fermentations. Appl. Microbiol. Biotechnol.. 39: 36-41, 1993.

26. Teixeira, M.F.S.; Santos, L.O.; Frota, M.Z.M.; Carvalho, S.M.D.S.; Dos Santos, K.S.B.; Da Silva, M.I.L.; Durán, N. Thermophilic and Thermotolerant Fungi Induced by Sawdust Mixtures (Decayed Laurel and Cedar Trees) at the Amazonian Region, Proc. Third Braz. Symp. Chem. Lignins and Other Wood Components, 4: 376-380, 1993.

27. Teixeira, M.F.S.; Fernandes, M.J.; Luna, E.A. Taxonomia de Aspergillus. Rev. Univer. Amazonas, Ser. Ciên. da Saúde. 3: 1-12, 1994.

28. Teixeira, M.F.S.; Fernandes, O.C.C.; Lima Filho, J.F., Durán, N. Screening of pectinolytic enzymes from thermophilic strains of Aspergillus from niger group. Biotechnol. Techn. submitted, 1998.

29. Tuttobello, B. R.; Mill, P. J. The pectic enzymes of Aspergillus niger. Biochem. J. 79: 51-56, 1961.

30. Wiseman, A. Handbook of Enzyme Biotechnology. 2a ed., England, Ellis Horwood Limited, 1985, 457p. 